\title{
ALTERNATIVE MINIMUM TAX
}

\author{
Şerif Emre GÖKÇAY ${ }^{1}$
}

\author{
Altan RENÇBER ${ }^{2}$
}

\begin{abstract}
One of the main problems of the Turkish Tax System is that the tax revenues of indirect taxes are very high compared to direct taxes. Taxpayers can reduce their income and tax burden by using exceptions, exemptions and reductions, and may state low income and / or tax base. In this case; the policy that should be implemented is to include into the tax system the people who must pay more taxes according to their economic. Implementation of this policy is not as easy as increasing the tax rates. Because it is necessary to determine the methods of tax exclusion and to block these methods.
\end{abstract}

Alternative Minimum Tax (AMT) is a compulsory alternative to the regular income tax in the United States. In this alternative; some taxpayers' liabilities are calculated twice once according to the regular Income Tax rules and once according to the AMT rules. This study will mainly focus on the AMT, which came into force in 1969 to struggle against similar problems in the United States. In order to better understand the AMT; general principles, historical development, purpose and its implication will be explained; the criticism of the structure of the AMT will be put forward and it will be explained whether such a tax will be benefited if it is implemented in Turkey.

Keywords: Income Taxation, Alternative Minimum Tax, Tax planning, Tax Avoidance

JEL Code: H25, H26, K34.

\section{Introduction}

One of the main problems of the Turkish Tax System is that the indirect tax rates in tax revenues are quite high compared to direct taxes. In Turkey in 2018, while the ratio of income taxes (income and corporate tax) in general budget tax revenues was 35.17 percent, it is observed that the ratio of value added tax and special consumption tax in domestic and imported expenditures was 52.25 percent (Revenue Administration, 2019). This is a problem in terms of the taxation principle according to the ability to pay. The main reasons for this problem is the high ratio of indirect tax on expenditures and the facility to avoid direct taxes. Taxpayers can reduce their income and corporate tax burdens by using exception, exemption and deductions, and they can lower their tax bases even if they obtain high income. This problem is often reflected in the press. In particular, the news reports that people in certain sectors pay very low taxes on their incomes (Hürriyet, 2002; Sabah, 2006; Habertürk, 2014).

Especially the increase in the tax rates come to mind in these days while the increase in the budget revenues is on the agenda. In fact, this method is effective and simple as well. Motor Vehicle Tax and corporate tax rate increases made last year are typical examples of this situation (Gökçay \& Altan, 2018: 120).

\footnotetext{
1 Asst. Prof., İstanbul University, Faculty of Economics, Public Finance Department Fiscal Law Division, emregokcay@gmail.com

2 Asst. Prof., İstanbul University, Faculty of Law, Fiscal Law Division, altanrencber@gmail.com
} 
This practice, which is effective and simple, is not suitable for tax justice. In this practice, the burden on the people who enter the tax system and carry the tax burden increases, but the effect is limited to those who are out of the system or who reduce the tax burden by tax planning or tax avoidance methods. This increases the inequity between taxpayers who pay their tax on time and the taxpayers who have the opportunity to plan and avoid it according to their real economic power (Gökçay \& Altan, 2018: 120).

In this case, the policy that should be implemented but not simple to implement is to include the economic powers of those who need to pay more taxes, but reduce the tax burden within the scope of the tax system. This policy is not as easy and simple as increasing tax rates. Because it is needed to determine these person's methods of tax planning and avoidance and take precautions against these methods.

In this study, the "Alternative Minimum Tax" (AMT), which has been developed in the United States to struggle similar problems, will be examined. In order to better understand this tax, first of all, the historical development of AMT, its general principles, its purpose and its implication will be explained; criticism of its structure will be revealed and it will be discussed whether such a tax will benefit from the application of our country.

\section{Historical Development of Alternative Minimum Tax}

AMT is a mandatory alternative to regular income tax in the United States. This alternative is implied in the form of calculation of some tax payers ' responsibilities twice - once in accordance with the regular income tax rules and once in accordance with the AMT rules - and then in the form of higher payments.

In 1969, Secretary of the Treasury Joseph W. The Barr reported to United States Congress that 155 tax payers with income exceeding \$200,000 did not pay federal income tax in 1966 . Thereupon that year Congress members received more constituent letters about those who did not pay their taxes than those related to the Vietnam War. The Congress, which could not remain indifferent to these pressures, made arrangements for the additional minimum tax that real persons would pay in addition to the regular income tax. This tax has been implied to certain items of income that have not been or low taxed under the scope of the regular income tax (Burman, 2007: 12 - 13).

In 1979, Congress adopted the AMT to implement a synonym for the additional minimum tax. Various income items have been transferred to AMT through additional tax. The Congress repealed the additional minimum tax in 1983 (Burman, 2007: 16).

Until the end of the 1990s, AMT has affected nearly 1 million taxpayers per year. Congress adopted The Economic Growth and Tax Relief Reconciliation Act (The United States Congress, 2001), which significantly reduced regular income taxes in 2001, but did not include a major change in AMT. The number of taxpayer subject to AMT has increased over the years since the inflation adjustment of the regular income tax levies was made but the inflation adjustment of AMT levies were not made (Tax Policy Center, 2005; Peckron, 2005: Ix).

On December 22, 2017, President Trump signed the "Tax Cuts and Jobs Act" (the United States Congress, 2017). With this law, an exemption was granted until 2025 even though AMT was protected. With this change, number of people affected by AMT fell to 200,000 in 2018 while 5 million people were affected by tax in 2017 (Tax Policy Center, 2005). 


\section{Purpose of Alternative Minimum Tax}

Exemptions, exemptions and reductions can significantly reduce taxpayers 'tax burdens. AMT is applied on the basis of restricting these facilities that reduce tax burdens of taxpayers who has more economic powers than they declare in their tax returns. AMT aims to taxpayers pay the minimum amount of tax (Internal Revenue Service, 2019; Peckron, 2005: x).

Some exceptions, exemptions and reductions permitted in the calculation of regular income taxes are not allowed in the calculation of AMT. This characteristic of AMT extends tax base (Peckron, 2005: $\mathrm{x}$ ).

However, the fact that the structure of AMT is not indexed to inflation can result in the increase of the tax burden over the middle income people instead of those in the upper income segment targeted to be included in the scope of the tax system ${ }^{3}$.

\section{Process Of Alternative Minimum Tax}

In order to determine whether there is any additional tax liability within the scope of AMT, the form no 6251 has to be completed. In the form no 6251, certain types of income and income or losses related to the disposal of the property are declared. This form also guides the taxpayer in determining whether the general limits set by the Internal Revenue Service for medical expenses, mortgage interest and other deductible expenses are exceeded.

AMT basis is calculated differently than the regular income tax base. Various expenses, exemptions and deductions that are permitted to be deducted in the regular income tax are not allowed in calculating AMT. At this point, the regular income tax and the calculation of AMT differ. In calculating the AMT basis, nondeductible discounts are added to the taxpayer's income and AMT exception is issued. In this way, the final AMT liability is calculated.

The calculation process of AMT liability is as follows (Peckron, 2005: 8-9):

1. Calculation of taxable income (according to the regular income tax). The calculation shall be made by taking into account the form no. 1040 .

2. Actualize various additions and deductions to taxable income.

3. Calculation of income subject to AMT

4. Take account of exceptions.

5. Calculation of AMT basis

6. Calculation of AMT

7. Deduction of taxes and other taxes paid abroad

8. Calculation of temporary AMT

9. Comparison to regular income tax

a) If AMT liability is more than the regular income tax liability, the difference will be paid (regular income tax liability and AMT difference calculated in the form No. 6251)

b) If the regular income tax liability exceeds AMT liability, the payment of the regular income tax lability will be paid

\footnotetext{
${ }^{3}$ In order to prevent this result, Congress enacted a law that indexed the AMT structure to inflation in 2015.
} 
As can be seen in the process, the first step in calculating AMT is to calculate the regular income tax on the basis of the explanations in the form No. 1040. After calculating the regular income tax, it is calculated whether various exemptions, costs and deductions that are not allowed within the scope of AMT are deductible under the exemption threshold for AMT (Peckron, 2005: 6).

The main deductions allowed in calculating AMT base are (Peckron, 2005: 24);

- Tax refunds (these are usually related to paid federal tax).

- Alternative tax net operating loss deduction

The exceptions and deductions that are not allowed in calculating AMT basis are as follows (Peckron, 2005: 24);

- Home Mortgage Interest (Mortgage interest can be reduced only if the loan is used to buy, build or improve the House.)

- Medical Expense

- Miscellaneous ( specified in the 5 line)

- Taxes (state, local, etc.)

- Interest from specified private activity bonds exempt from the regular tax

- Net operating loss deduction

- Personal Exemption (Instead of listing personal exemptions in the form No. 6251, the income subject to tax before personal exemption is taken into consideration in the form).

- Standard Deduction (instead of listing the regular deductions in the form No. 6251, the income subject to tax before the standard deductions in the form is taken into consideration.

Exception limits for AMT are as follows;

- $\$ 109.400$ for married filing jointly and surviving spouses

- $\$ 70.300$ for single or head of household

- $\$ 54.700$ for married filing a separate return

The exception limit is quite high compared to 2017 . The exception limit, which was 109,400 dollars in 2018, was increased from $\$ 84,500$ and the limit of 70,300 was increased from $\$$ 54,300 (Carlson: 2018).

Those who earn income above these limits must pay AMT. However, in this case, the relevant limits constitute an exception amount. For example, a single peson who has $\$ 95,000$ in income will pay this tax for the remaining $\$ 24.700$ after $\$ 70.300$ is deducted from $\$ 95,000$ (Peckron, 2005: 5).

Although the AMT's exception amount is above the regular income tax, the exception amounts begin to decline after the person's income rises above a certain level called "Phase-out". According to this, the exception for each dollar exceeding this level is reduced by 0.25 dollars if more than $\$ 1.000 .000$ for married couples and more than $\$ 500,000$ for others. It should be noted that these ratios have been increased by "Tax Cuts and Jobs Act" from 2018 to 2025. In 2017, these ratios were 160.900 dollars for married couples who completed the form together, 120.700 dollars for single and/or family head return, and 80.450 dollars for those who are married and separate returns (IRC, 26; Amadeo: 2019). 
AMT has an increasing tariff of two rates. Accordingly, in 2018; the person who makes the income up to $\$ 19.100$ of the exemption amount will pay $26 \%$ and the person who makes the income over this amount will pay the tax rate of $28 \%{ }^{4}$. Therefore, AMT's proportional structure is only a 2-ratio structure, contrary to the usual income tax between 10\% and 37\% (Peckron, 2005: 14).

If the amount calculated by taking into consideration the allowed/not allowed expenses and discounts in the form No. 6251 and the AMT exception amount is more than the regular income tax calculated on the basis of the form No. 1040, the taxpayer is obliged to pay the difference (IRC: 26; Amadeo: 2019; Peckron, 2005: 12 - 13).

AMT calculation is an obligation to be performed by taxpayer every year. The absence of AMT liability in one year does not affect AMT liability in the following year (Peckron, 2005: 12).

\section{Criticism of The Structure of Alternative Minimum Tax}

It should be noted that the purpose of AMT is to tax those who have high economic power, but who pay less taxes within the facilities of tax planning or avoidance. But in fact the middle income people included in the scope of AMT (Burman, 2007: 22). The main criticism of AMT is that the expense, discount and exception structure in this tax transferred the tax burden over the middle income class instead of the high income class (Peckron, 2005: 1-2).

In addition, increasing the complexity of taxation and making tax planning difficult are other criticisms (Burman, 2007: 18; Peckron, 2005: 14).

It is assumed that an effective tax system will promote economic efficiency or at least not undermine efficiency too much. However, it is stated that most of the taxpayers will actually face higher tax burden than the regular income tax and this will adversely affect the decisions regarding labor supply, consumption and saving (Burman, 2007: 18).

\section{Conclusion}

AMT is a mandatory alternative to regular income tax in the United States. This alternative is applied in the form of calculation of the responsibilities of some tax payers twice and payment of the high amount.

Exemptions, exemptions and reductions can significantly reduce taxpayers ' tax burdens. AMT aims to limit these possibilities to reduce the tax burdens of taxpayers with high economic powers and to provide the minimum amount of tax payments.

Some exceptions permitted in the calculation of regular income taxes are not allowed in the calculation of AMT. At this point, the calculation of regular income tax and AMT is different. This property of AMT extends tax base.

In calculating the AMT basis, discretionary discounts are added to the taxpayer's income and AMT exception is issued. In this way, the final AMT liability is calculated.

AMT is criticized for the fact that the tax burden remains above the middle class, increases uncertainty in taxation, makes tax planning difficult, and reduces economic efficiency.

\footnotetext{
4 In the United States, income tax has an increasing rate of tariff as in our country. According to this percentage $10,15,25,28,33,35,39.6$ rates updated to 10, 12, 22, 24, 32, 35 (Smith \& Howard: 2018).
} 
In the Turkish tax system, the fact that taxpayers can reduce their income and corporate tax burdens by using exceptions, exemptions and deductions and show their income tax base above their economic powers even if they obtain high income generates negative results in terms of efficiency and fairness in taxation.

In particular, the use of these tax conveniences by certain sectors and income groups intensifies the tax burden on indirect taxes and paid cuts.

In the New Economy Program (2019-2021), in the context of public finance, it is on the agenda as a policy measure to gradually increase the tax base by removing the exemptions and deductions that are not effective in order to consolidate justice in the tax.

The constitutional principles of tax (especially the principle of ability to pay) should be taken into account and initiate a discussion whether it is necessary to generate an alternative income tax in the Turkish tax system.

\section{References}

Amadeo, K. (2019). What Is the Alternative Minimum Tax? Who Has to Pay?, https://www. thebalance.com/alternative-minimum-tax-amt-who-has-to-pay-3305784 (05.02.2019).

Burman, L. E. (2007). "The Alternative Minimum Tax: Assault on the Middle Class", Milken Institute Review, Fourth Quarter 2007, ss. 1-23.

Carlson, B. (2018). What You Need to Know About The New Alternative Asgari Tax, https:// www.forbes.com/sites/bobcarlson/2018/09/29/what-you-need-to-know-about-the-newalternative-minimum-tax/\#591b19284822 (06.02.2019).

Gelir İdaresi Başkanlığı (Revenue Administration). (2019). 2018 Yılı Merkezi Yönetim Gelirleri, http://www.gib.gov.tr/sites/default/files/fileadmin/user_upload/VI/GBG/Tablo_21.xls. htm, (05.02.2019).

Gökçay, Ş.E. \& Rençber, A. (2018). "Aktarılmış Kazanç Vergisi Uygulaması (Diverted Profit Tax) ve Türkiye Açısından Uygulanabilirliğinin Değerlendirilmesi”, Maliye Araştırmaları - 2, (Ed.) İpek S., Bursa, Ekin, ss. 119-134.

Habertürk. (2014). Ye kürküm ye!, https://www.haberturk.com/ekonomi/para/haber/1004245ye-kurkum-ye, (05.02.2019).

Hürriyet. (2002). Kuyumcu, işçiden az vergi ödüyor, http://www.hurriyet.com.tr /ekonomi/kuyumcu-isciden-az-vergi-oduyor-75880, (05.02.2019).

Internal Revenue Service (IRS). (2019). Topic Number 556 - Alternative Minimum Tax, https:// www.irs.gov/taxtopics/tc556, (05.02.2019).

Peckron, H.S. (2005). Alternative Minimum Tax What You Need to Know About the "Other" Tax, Illinois, Sphinx.

Sabah. (2006). Patronlar işçilerden az vergi ödüyor, http://arsiv.sabah.com.tr/ 2006/03/23/eko98.html, (05.02.2019). 
Smith \& Howard. (2018). 2018 Tax Cuts \& Jobs Act Overview, https://www.smith-howard. com/2018-tax-cuts-jobs-act-overview/, (05.02.2019).

Tax Policy Center. (2005). Briefing Book, "Key Elements of US Tax System", https://www. taxpolicycenter.org/briefing-book/what-amt, (05.02.2019).

The United States Congress. 2001. The Economic Growth and Tax Relief Reconciliation Act, https://www.congress.gov/107/plaws/publ16/PLAW-107publ16.pdf, (05.02.2019).

The United States Congress. 2017. Tax Cuts and Jobs Act, https://www.congress.gov/bill/115thcongress/senate-bill/2254?q=\%7B\%22search $\% 22 \% 3 \mathrm{~A} \% 5 \mathrm{~B} \% 22 \% 5 \mathrm{C} \% 22 \mathrm{Tax}+$ Cuts+ and+Jobs+Act\%5C\%22\%22\%5D\%7D\&s=5\& $r=8,(05.02 .2019)$. 